\title{
Commemorating Deng and criticising the "left"
}

Compiled and Commented Analysis

\section{Michal Meidan}

\section{(2) OpenEdition}

\section{Journals}

Electronic version

URL: http://journals.openedition.org/chinaperspectives/1793

DOI: $10.4000 /$ chinaperspectives. 1793

ISSN: 1996-4617

\section{Publisher}

Centre d'étude français sur la Chine contemporaine

\section{Printed version}

Date of publication: 15 April 2007

ISSN: 2070-3449

Electronic reference

Michal Meidan, « Commemorating Deng and criticising the "left" », China Perspectives [Online], 2007/2 |

2007, Online since 09 August 2012, connection on 15 September 2020. URL : http://

journals.openedition.org/chinaperspectives/1793

(C) All rights reserved 

aiming to reflect the point of view of the People's Republic of China on international questions and issues related to Greater China.

\title{
Commemorating Deng and criticising the "left"
}

\author{
Compiled and commented by Michal Meidan based on: \\ - Yuan Weishi (1), "Seize the historical opportunities; arm oneself with courage and ingenuity, promote the reform process," \\ Nanfang dushi bao [Southern Metropolis News], 29 January 2007, editorial page. \\ - Unattributed article, "China remains on the road of reform and opening," Xinhua, 19 February 2007.
}

$\mathrm{T}$

wo memorials dates were highlighted in January and February 2007: the first commemorated the death of Deng Xiaoping on 19 February 1997, the second commemorated his famous "southern tour", which relaunched the economic opening after the Tiananmen incident.

In a turbulent political context leading up to the 17 th Congress of the Chinese Communist Party (CCP) this autumn, the political and economic legacy of Deng Xiaoping is being invoked by the partisans of a vigorous pursuit of reforms in reaction to certain "leftist elements" in the government. Hu Jintao and Wen Jiabao have clearly positioned themselves as "Dengist" reformers. A series of articles that have appeared in the official media identify this pair in the continuing line of a liberal legacy, both economic and political, by proclaiming a desire to rectify the problems, primarily the growing income gap that is the most significant unintended consequence of Deng Xiaoping's programme.

The official media praises the economic gains resulting from Deng's reforms but broaches the subject of political reform more circumspectly. It nevertheless also pays attention to its successes, in particular the stable and successful political transition between the third and fourth generations, the promulgation of laws and new regulations and, above all, the fight against corruption.

Yuan Weishi goes further in his analysis. His eulogy of Deng Xiaoping is no less glowing than that of the official press agency, Xinhua, but it is used here as an argument to plead against a turn to the left.
The controversial author uses Deng's legacy, with manifold quotations from his works, to make the case for the pursuit of economic reforms, participation in the WTO and China's integration into the process of globalisation: "no economic solution requires abandoning this path". According to him, the fear of globalisation and increased liberalisation of the markets emanates from the feeling that these may endanger national security or lead to a recolonisation of China, this time by foreign capital. The response, argues the author, does not need to take "non-peaceful" paths; indeed, the pursuit of China's integration into global trends would render these fears trivial.

The world today, argues the author, is built on economic foundations and on the maximisation of profits, but the tradition of struggle [a reference to the Maoist notion according to which all progress stems from a process of struggle] and the feeling that China has been a victim of imperial powers can no longer guide the country. Certainly, some states intervene in the economic life of their country, but that does not change the fundamentally commercial character of international relations.

Second, some people in China are incapable of breaking free from the Soviet model, which "was a political, econom-

1. A history professor at Sun Yatsen University in Guangzhou, Yuan Weishi is the author of an article that was published on 24 January 2006 in the magazine Freezing Point (Bingdian), a supplement of the China Youth Daily, that openly criticised the CCP for its presentation of the Boxer Rebellion in history textbooks. The magazine was shut down as a result of the article. 
ic, cultural and ideological tragedy". It leads these people to favour economic planning to the detriment of the markets, as well as direct control of enterprises and a monopoly of the markets. What's more, "[these people] despoil academic work and [undermine] freedom of thought and expression". The author similarly denounces the intervention of politics in economic choices: China, according to him, has missed too many historical opportunities; it is essential not to let others slip past, he warns, thus echoing the words of premier Wen Jiabao ${ }^{(2)}$.

But the biggest challenge to be faced, in his view, remains that of the rule of law. Corruption, an anarchic market, the gap between rich and poor and a weak capacity for innovation are the four big questions that will determine China's future. He thus calls for constitutional reform. The principles of the rule of law have been incorporated in the country's constitution, and the leaders have openly talked about the importance of this reform. For all that, however, its implementation is slow, even if the "citizens" are increasingly aware of their rights and freedoms ${ }^{(3)}$ and increasingly seeking the support of lawyers and the media. "Civil organisations are developing and giving a voice to victims of injus- tices", but the system has to integrate the protection of these rights, failing which it will remain impotent.

The targets of the editorial by Yuan Weishi, one year after Bingdian was shut down, are primarily the propaganda departments that were responsible for the closing of the newspaper's supplement and for the banning of the publication of eight works ${ }^{(4)}$ that reviewed the historical and social events of China's modern history. The author's criticism stays, prudently, within the limits of the themes of the debates that make the front pages of the Chinese press in a more consensual way. His remarks are nevertheless made in a context of political transformation and debate within China concerning the limits of the reforms to be followed.

Despite this critical editorial and a tendency to claim a growing liberalisation, $\mathrm{Hu}$ Jintao seems to be pursuing a line of gradual and, above all, consensual reform ${ }^{(5)}$. The recent promotions of provincial leaders and the new ministerial posts translate the balance that $\mathrm{Hu}$ strives for with the other political factions. Yuan Weishi's article, albeit critical, employs for this purpose a politically correct terminology, but is still a patent manifestation of the debates that are preoccupying the Chinese intelligentsia.

2. See "Institutional culture according to Wen Jiabao" in the same edition of China Analysis.

3. See the recent work by Kevin 0'Brien and Lianjiang Li, Rightful Resistance in Rural China, Cambridge University Press, 2006.

4. "Eight books banned in crackdown on dissent," South China Morning Post, 19 January 2007.

5. Willy Wo-Lap Lam, "Striving for Balance: Assessing Recent Municipal and Provincial Leadership Changes," China Brief, vol. 7, n 2, 18 April 2007. 